\title{
CANCEL CULTURE; THE SCARLET LETTER IN GABRIELA PUGLIESI'S CASE
}

\author{
CULTURA DO CANCELAMENTO: A LETRA \\ ESCARLATE NO CASO GABRIELA PUGLIESI
}

\section{Nathalia de Oliveira Nunes}

Mestra em Comunicação pela Universidade Federal do Rio Grande do Sul (Porto Alegre/Brasil). Pesquisadora do Laboratório de Interação Mediada por Computador na Universidade Federal do Rio Grande do Sul (Porto Alegre/Brasil).

E-mail: nnathalia@gmail.com 


\section{Brazilian

\section{ABSTRACT}

The following paper presents definitions of the cancel culture phenomenon on the internet, bringing concepts based on shame, public humiliation, and reputation according to Solove (2007) and Ng (2020). Focused on digital influencers, draws parallels between public humiliation practices adopted in the Middle Ages - such as a scarlet letter embroidered on clothes - and current ways to promote virtual lynching in social media websites. Through the study of mediatic coverage of Gabriela Pugliesi's canceling, presents an initial framework for the process of canceling digital influencers, taking into consideration the practices of these content creators as it relates to the relationship with the brands and the transformation of private space into public space.

Keywords: Digital Influencers. Cancel Culture. Public Humiliation.

\section{RESUMO}

O artigo busca apresentar definições para o fenômeno de cancelamento na internet, trazendo conceitos baseados em vergonha, humilhação pública e reputação a partir da análise de Solove (2007) e Ng (2020). Com foco nos influenciadores digitais, traça paralelos entre as práticas de humilhação pública utilizadas na Idade Média - como o uso da letra escarlate bordada na roupa - e das atuais formas de linchamento virtual ocorridas nos sites de redes sociais. Por meio do estudo da cobertura midiática do cancelamento de Gabriela Pugliesi, apresenta um modelo inicial do processo de cancelamento de influenciadores digitais, levando em conta as práticas desses produtores de conteúdo no que diz respeito ao relacionamento com marcas e a transformação do espaço privado em público.

Palavras-chave: Influenciadores Digitais. Cultura do Cancelamento. Humilhação Pública. 


\section{Brazilian \\ Creative Industries}

\section{INTRODUCTION}

Much has been said about how the internet allowed content creators from all sizes to break through the traditional media walls and reach different audiences. Solove (2007) refers to this effect by mentioning that we all became content creators and broadcasters in some way, resulting in a bullish trend in the beginning of the 2000's. Researchers like Shirky (2008) were optimistic about the transformational power of technology in communications, economy and human interactions overall. However, Solove raises the dark side of this process: gossip and rumors also moved over to the Internet, making the information that was once scarce and easily forgettable into permanent and accessible by any search engine. Questionable information - oftentimes fake or slanderous - is available, as well as embarrassing facts that could hurt one's reputation. These records can affect our ability to define our own identities, participate in public activities and even get a job. In a paradox, the huge amount of information available in the web can become a hindrance to civil liberties and privacy.

This process has an impact over all internet users, but its influence can increase in parallel with the exposure and fame of the individual. Thus, the common user is subject to these concerns, but in a smaller degree than that of a public person or even a digital influencer. Karhawi (2017) mentions that an influencer is a professional in the communications field, one that builds relationships with brands, businesses, and people, all converted in monetary gains. Once the nature of their activity is deeply connected with the brands to whom they partner, there's a market imperative for influencers to build, generate and manage a positive reputation in the digital environment. This process revolves around building credit and social capital, creating hubs and engaging a community by their posts.

However, the relationship that influencers establish with their audiences doesn't follow the transmissionist communication model, according to which influencers would act as broadcasters to a passive audience, who just consumes or adopt habits defended by them. The audience that engages with digital influencers is consistently active and, in some cases, stands up against messages developed by the creators. This reaction, that oftentimes occurs by a massive number of negative mentions or even derailing hashtags on Twitter and Instagram, originates what we call "cancel culture". The goal of this article is to present some definitions to the phenomenon and, by leveraging pieces of media coverage from the recent episode with Gabriela Pugliesi, map the process of canceling digital influencers. 


\section{Brazilian \\ Creative Industries}

\section{CANCELLING: REPUTATION AND PUBLIC SHAMING ON THE INTERNET}

$\mathrm{Ng}$ (2020) defines cancel culture as the withdrawal of any type of support - rather it's site views, social media followers, purchase of sponsored products by an influencer, etc. - to those that are judged for doing or saying something unacceptable or highly problematic. The author emphasizes that these faults often occur under a social justice perspective, especially as it relates to topics like sexism, homophobia, racism, and bullying. Although Ng traces back to the first mentions of "canceling" on Twitter in 2015, the \#MeToo movement is considered one of the starting points for these types of behavior on the Internet. With the purpose of exposing sexual harassment and giving voice to the victims, the same force that was once used with a laudable goal started to present the perils of mob mentality. In this specific case, Harvey Weistein, - the culprit that eventually went to trial for these crimes - didn't have social media accounts to be effectively cancelled. However, a significant number of individuals that were subsequently accused felt the effect on social media, including actor James Franco and singer R. Kelly. It's also relevant to notice that in this case, the men that were accused were charged and faced legal restrictions - which didn't seem to be the case for the cancel effect moving forward.

Hou, Jiang e Wang (2017) state that public shaming acts - that were transposed to the Internet and constitute the core of cancel culture - reflect a form of vigilantism, by which people enforce social control when the established order is under a threat of transgression. Still exploring this concept, authors sustain that this vigilante role is defined by external sanctions happening via the Internet, with the inherent capacity to broadcast information much faster and breaking through geographical and cultural barriers, which makes its effect particularly pervasive. Following up on the discussion about vigilantism, Ng (2020) argues that cancel culture usually takes place among groups that were previously silenced, finding in this form of activism a way to attack the power held by those traditionally privileged by their genre, race, etc. It's also worth noticing that the confrontational behavior quickly escalates to mass trial, getting to a point of harassment. The result is that individuals that would be guilty of violating social norms (and even civil rights) become subjects of online shaming.

Public shaming is not a new form of social coercion - quite the opposite, as it's part of human's history in a plethora of different practices. Vries (2015) presents a list of examples such as flagellation, branding, amputating thieves' hands, and public execution. One of the most famous is the scarlet letter, that was attached to one's clothing to highlight illicit behavior, a central plot in Nathaniel Hawthorne's romance. In the novel, the main character carries the scarlet letter " $\mathrm{A}$ " embroidered in her chest, qualifying her as an adulteress. All these forms of public shaming serve the purpose of acting as a reminder to the wider community and punishing the blameworthy behavior. Some of them are still used (for instance, 


\section{Brazilian \\ Creative Industries}

wearing visible jackets for community service in the UK), although the author argues that the relative power of them diminished as populations increased and families migrated to the cities, as well as with prisons becoming institutionalized. Therefore, once the community ties became weaker, public shaming lost its strength as a penal technique and deterrent act.

Enter the Internet promoting closeness between groups that were once geographically far away. Now, these groups can form communities of interest and interact in social media sites, which is the case of Twitter. In that way, shaming doesn't happen in a public space, in front of the neighborhood and acquaintances, but in the virtual settlement. The threat to character and reputation, however, remains the same (or even bigger, considering the reach of internet communications). Solove (2007) states that reputation is also a dimension of the self, something that affects our own identity. Beyond its internal influence in our inherent values, reputation affects our ability to perform basic activities among society. We depend on each other to form friendships, to have dialogues and even get jobs and establish commercial relationships. Without cooperation - a consequence of respect - our actions and achievements may lose their purpose. Without reputation, even our own speech (although free) finds a deaf audience. In a certain way, as the author states, our own freedom depends partially on how society judges us.

Beyond the individual liberty perspective, reputation is also a currency for relationships: we decide who to trust based on their reputation. Trust and believing one's words are the foundation for social order. Solove (2007) states that, beyond offering individuals the opportunity to defend themselves against dishonesty, reputation also plays a social control role. By making sure that people are responsible for their acts, reputation offers a strong incentive for conformity with social norms and the satisfaction of other's expectations. Hou, Jiang and Wang (2017) write about the theme stating that online shaming can help to reestablish social norms that were broken by the offender, stopping him or anyone else from attempting the same again. Thus, the authors point to conformity with social norms and, therefore, regulation of the self and the others as a reason for cancelling someone. Following through this idea, another reason for cancelling would be to exercise social control, in hopes to increase ties between groups and avoid deviations, reinforcing a certain type of behavior as acceptable and respectable within a community.

Vries (2015) confirms this point of view by stating that public shaming can be a way to regulate social norms - regular behavior rules that coordinate human interaction. They compound multiple areas of life, guiding behaviors and affecting our perceptions as it relates to one another. The maintenance of these social norms is achieved by informal sanctions, and with that in mind, shaming and humiliation can play an effective mechanism. Elster (2009) goes further by mentioning there's a social obligation to expose those who violate pervasive social norms, which seems to have quickly spread through the 


\section{Brazilian \\ Creative Industries}

cyberspace. Considering the abovementioned definitions of cancelation and taking Vries (2015) approach, some basic characteristics for virtual shaming are adapted below:

a) Cancellation targets individuals or brands (even though it usually happens with individuals).

b) Cancellation is conducted by regular individuals, instead of Government or public and private institutions.

c) The behavior that leads to cancellation can be legal or illegal but is always judged as immoral or unethical.

d) The audience of social media plays a critical role as a facilitator and broadcaster of public shaming.

Considering influencers, it's worth noting that a key aspect is the impact on their reputation, which constitutes a critical factor for monetizing their work. Ortiz (2016) states that celebrities are an outcome of modern mass media, associated to some sort of production line of fame - which is evident in the work of building and sustaining an audience done by digital influencers. Ortiz's point resides in the fact that mass media plays an important part in this process, offering to people a variety of opportunities that can equally integrate them on social. These opportunities are the building block of the process that allows an unknown individual to reach fame only by leveraging social media.

However, the same democratization of social roles comes with a price: while the consolidation of the celebrity status is happening faster, the same status can fall apart in a short timeframe, representing its ephemeral character. A hallmark of the society we currently live is the loss of individuality and the transformation of public spaces, a key phenomenon for the rising of celebrities: "to transform in something worthy of attention, the individual cannot be confined to its privacy; said privacy needs to be projected in a field shared by public opinion" (ORTIZ, 2016, p.675). But aren't influencers subject to cancelation exactly because of this loss of public space? To analyze further into these questions, we propose the case study of the Brazilian influencer Gabriela Pugliesi.

\subsection{GABRIELA PUGLIESI AND A LONG HISTORY OF CANCELLATIONS}

According to the dossier published by Área de Mulher from R7, Gabriela Pugliesi is one of the most well-known digital influencers in Brazil, considering she has over four million followers on Instagram. Her content is focused on lifestyle, sharing tips on exercise and sports, healthy diets, travelling, spirituality and nature connectedness. Despite positioning her account as a personal profile, the influencer promotes her work, exhibiting contacts for professional partnerships in her bio, as shown in PIC 1: 


\section{Brazilian \\ Creative Industries}

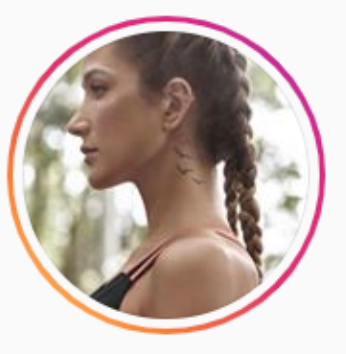

Picture 1: Gabriela Pugliesi's Instagram Bio

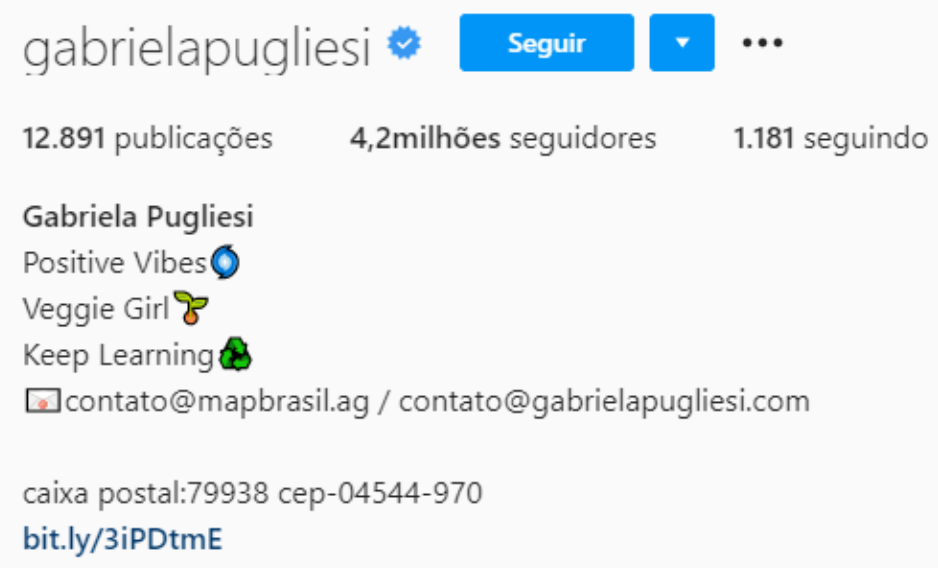

Source: https://www.instagram.com/gabrielapugliesi/?hl=pt-br

Moving forward with the description provided by R7 dossier, Gabriela decided to transform her lifestyle at the age of thirteen, enrolling at the gym and adopting healthier habits. Her career as a fitness blogger began in 2012, with Instagram publications showing her body transformation. Pugliesi is graduated in industrial design, and before starting her project on the Internet, she used to work at a jewelry store. In 2013, she quit her formal job and started to focus exclusively on her blog, Tips4life. On this blog, Gabriela promoted healthy diet tips, physical exercises and other topics related to the fitness universe. As she gradually became well-known on the Internet, brands started to reach out looking for partnerships, merchandising and even creating special products with her name. Nowadays, aside from the blog, Gabriela owns a Youtube channel - Vendi meu Sofá - in which she posts a series of interviews with celebrities talking about lifestyle. Even though the platform has over 700K subscribers, its on Instagram that Gabriela holds most of the interactions, and where she establishes frequent contact with her followers by posting stories. It's also on this channel that she promotes brands by leveraging sponsored posts, which are responsible for a huge part of her revenues as an influencer.

Meanwhile, Pugliesi's journey on social media is stained by controversies, especially with labor unions. In November 2015, on videos shared on her Snapchat profile, the influencer suggested her followers who wanted to lose weight should have send nudes to their best friends, authorizing them to publish the pictures in case they failed their diets, as punishment. The Regional Union of Nutritionists published a repudiation letter against non-professional advice on weight loss, qualifying such acts as irresponsible. Besides, the union filed a lawsuit against Gabriela based on illegal exercise of the occupation. Despite all that, the fitness blogger was cleaned from all charges in 2017. Constantly accused of promoting weight 


\section{Brazilian \\ Creative Industries}

loss at all costs, the influencer received a criminal complaint by Rio de Janeiro and Espírito Santo's Regional Union of Physical Education for illegally exercising the trade, as the newspaper O Globo reported back then. Gabriela was allegedly teaching gymnastics classes at Praia da Barra, during a commercial event.

While these incidents certainly received media attention, none of them was so damaging to Gabriela's reputation as the event that happened during the coronavirus pandemic. In the second week of March, at the beginning of quarantine and social distancing in Brazil, the influencer's sister got married in Trancoso - which resulted in a lot of guests contaminated by the virus, including Gabriela herself. Right after that, the blogger posted content on her Instagram praising the bright side of the pandemic, which led to accusations of romanticizing the virus and ignoring her own privileges in contrast with many deaths occurring in Brazil. The post, whose title was "Thank you Coronavirus" was deleted from her social media right after the negative coverage.

A few weeks after recovering from Covid, Gabriela hosted a party at her house on April 25th, in São Paulo. She gathered a group of friends and influencers at her residence, disrespecting recommendations to avoid meetings and crowds, even within private houses. The fitness influencer hosted a party of approximately ten guests and published photos and videos on her Instagram account - both on her feed and on her stories, where one can see guests with no masks or any kind of protection.

The negative impact was immediate, with a lot of comments from her followers on Instagram and Twitter, causing Gabriela to delete the images a couple of hours after posting it. Nonetheless, the action wasn't enough to avoid public shaming, even after posting an official statement in the following afternoon. In a video, the influencer apologizes, stating she drank too much and regretted her irresponsible and immature actions. Gabriela kept facing harsh critics on the comments of her post, being called out by followers and celebrities that despised her actions. Some of the Twitter posts are presented on PIC. 2, PIC. 3 and PIC. 4:

\section{Picture 2: Twitter Comments}

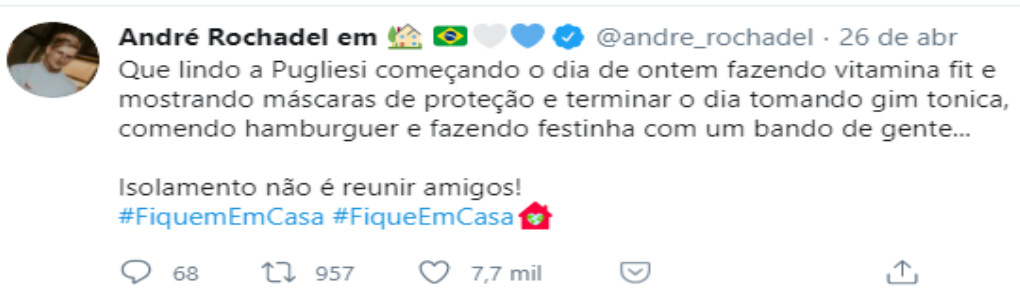

Source: https://twitter.com/andre_rochadel/status/1254399221186297862, 


\section{Brazilian

\section{Picture 3: Hostile Comments on Twitter}

OBERON $\nabla$ @ @eduardopaixao38.26 de abr

Gabriela Pugliesi fazendo festa em plena pandemia. E a única coisa que me ocorre é: por que as pessoas insistem em transformar gente estúpida em celebridade?

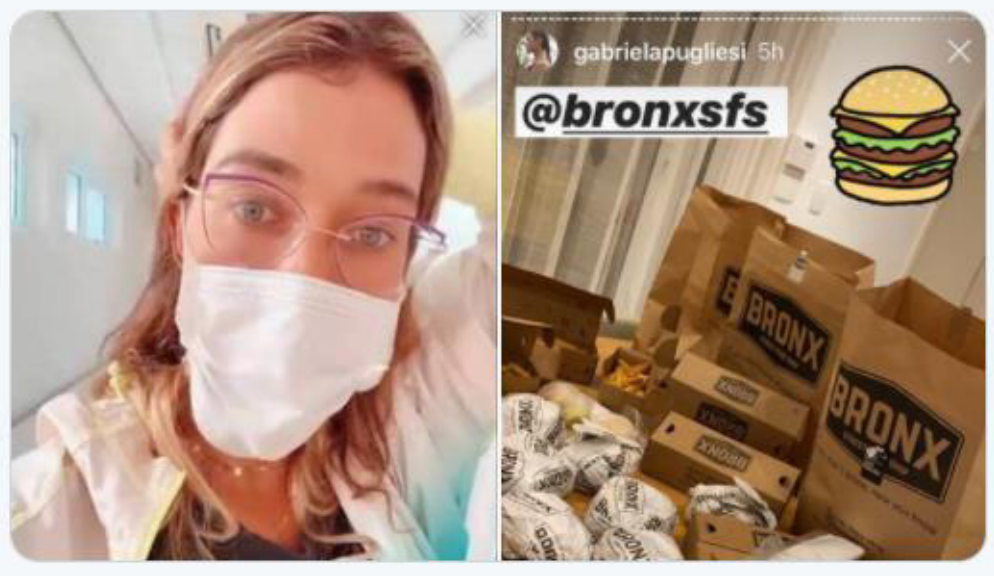

Source: https://twitter.com/eduardopaixao38/status/1254393521399832576,

\section{Picture 4: Cancellation comments on Twitter}

ANTIFA@legalizandra.26 de abr

todo dia a pugliesi dando um novo motivo pra ser cancelada essa mulher é uma vaca imbecil como pode ainda ter alguma credibilidade? geração saúde de quem?

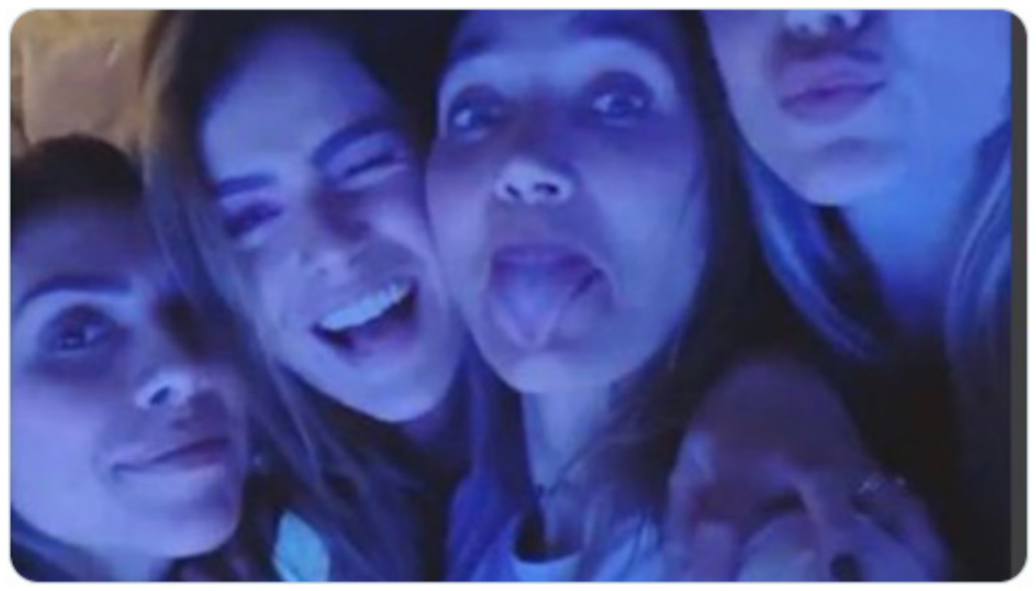

Source: https://twitter.com/legalizandra/status/1254393687473348610

Brands who used to partner with Gabriela also faced intense backlash on social media. Multiple users searched for brands' social accounts, demanding a statement about the influencer behavior, and 


\section{Brazilian Creative Industries}

threatening the corporate reputation of said companies. As an outcome, brands worked to separate themselves from the blogger, reinforcing this attitude through social media posts. According to G1, Grupo Hope, Rappi, LBA, Baw Clothign, Mais Pura, Evolution Coffee, Desinchá, Liveup, Kopenhagen and Fazenda Futuro released official statements against Gabriela's actions, following up with the immediate suspension of commercial partnerships with her. While some brands didn't specifically address the topic, others were very outspoken about the disagreement, as one can see in Liv up's post in PIC 5:

\section{Picture 5: Live Up breaks contract with Gabriela Pugliesi}

\section{Liv Liv Up \\ @livupoficial}

Não incentivamos atitudes que possam colocar a saúde de qualquer pessoa em risco, assim, estamos suspendendo todas as ações que tínhamos programadas com a influenciadora e adiantamos que esse é nosso posicionamento em qualquer outra situação similar. 12:47 PM · Apr 26, 2020

Source: https://twitter.com/livupoficial/status/1254452270831407105

The result of these contractual losses, in numbers, was estimated by Folha in approximately three million reais. The math was done through a research led by Brunch, a company responsible for managing influencers and their careers. In a nosedive, Gabriela lost more than $150 \mathrm{~K}$ followers and deactivated her Instagram account, coming back to social media in the end of July, nearly three months after the fact. Deactivating her Instagram account was considered a strategic move, since the effort avoided further losses of followers (when Pugliesi got back to the social media platform, her number of followers was restored to that of the moment when she froze her account).

\section{CANCELATION PROCESS: AN INITIAL FRAMEWORK}

The events that followed Gabriela's party are a practical example of the cancelation definition that $\mathrm{Ng}$ (2020) introduces: right after images of the event going viral, there's been an escalated process of withdrawal of support, both from the audience and associated brands. Pugliesi lost followers, engagement, sponsors, and contracts because of her problematic actions. In that sense, the fact is in line with criteria mentioned by Vries (2015): although her demeanor wasn't illegal, it was judged as extremely unethical during the quarantine and social distancing period, when society held an informal pact to avoid gatherings, keeping relationships limited to those living in the same household. 


\section{Brazilian \\ Creative Industries}

Still on the social pact topic, it's worth raising Hou, Jiang and Wang's (2017) vision, reinforcing that cancelation is oftentimes used to reestablish social norms that were violated, keeping up the surveillance on deviant behavior. The months of March and April 2020 were the beginning of the pandemic in Brazil, a time during which many governments and the media recommended total isolation, guiding people to only leave their houses to execute critical activities. Gabriela's party broke this informal rule, causing the vigilantism mentioned by the authors. Beyond the quick escalation that usually happens on social media, there's an aggravating point: the celebrity status held by the influencer contributed heavily to the widespread of the cancelation. Since exposing her routine on the Internet and opening her intimacy to build a relevant reputation for her affiliate brands is part of Gabriela's job, she was way more vulnerable to crisis than a regular social media user.

Modern society doesn't engage in public shaming with the tools mentioned by Solove (2007), such as maiming or the scarlet letter from Nathaniel Hawthorn's book. However, one could argue that the scarlet letter left the local community and was transferred to social media, affecting one of the most important assets for digital influencers: reputation. Aside from playing a critical role to monetize their jobs, since content creators rely on trust from the audience and from the brands to dialogue and endorse products, there's another layer related to identity and how we insert ourselves in the world. Gabriela Pugliesi's actions, while questionable from an ethical and moral standpoint, were repelled in a way that not only her professional relevance was damaged, but even her own values and beliefs. Cancelling silenced the blogger, stopping her from having a dialogue with her audience, which one can see even in the video where she apologizes for her actions.

Pugliesi's speech landed on a hostile and deaf audience(SOLOVE, 2007) once there was no willingness or respect to engage or even react to her statements. Brands continued to push back, comments were increasingly slanderous, up until the point where the woman withdrew from social media, deactivating her account for nearly three months. It's a digital ostracism process: just like leprous people were excluded from the old communities, Gabriela was expelled from the "virtual village", having a trial executed by a vigilante mob. While her actions were irresponsible, they are beyond the focus point of this discussion. More than stating a value judgement over her demeanor, the point authors bring up is how social media mobs are capable of silencing people, without a formal or any type of civil action to back their decisions up. There's a huge difference between Harvey Weistein's crime (which in fact went to trial) and the scandals involving celebrities, but the point here is to highlight how social media can move from a tool that gives voice to these minorities and amplifies protests, to a vigilantism asset.

Considering these facts and taking the model designed by Vries (2015) as a starting point, we propose an initial process outlining the steps to cancelling digital influencers: 


\section{Brazilian \\ Creative Industries}

a) Influencer establishes reputation: processes of content creation and authority building, involving the transformation of private into public space with the goal of attracting and managing an audience (the production line of fame, as stated by Ortiz, 2016).

b) The audience builds expectations and, therefore, develops a vigilante type of behavior related to social norms and exemplar conduct, in line with the reputation established through the content published on social media.

c) Exposure of vexing and immoral behavior (considering the established social norm), although not necessarily illegal. (Vries, 2015).

d) Audience reaction, leading up to a reputation pushback and sanctions as it relates to the influencer voice and speech, getting to the point of breaking up contractual partnerships and sponsored agreements. It's the de facto cancellation, which may or may not come with a formal apology and time away from social media (freezing accounts, just like Gabriela Pugliesi did).

\section{FINAL CONSIDERATIONS}

The goal of this article was taking the theoretical approach proposed by Solove (2007) and $\mathrm{Ng}$ (2020) to present a discussion on public shaming and reputation. Hou, Jiang and Wang (2017) and Vries (2015) are authors that draw parallels between publish shaming methods used in Middle Age and their transposition to the Internet. They affirm this can be considered the building block of cancel culture. Aside from that, Karhawi (2017) and Ortiz (2016) present definitions of digital influencers and discuss the role of celebrities that, because of the nature of their jobs, are exposed to way more hate speech and repel on social media.

To follow through with the goals of presenting cancel culture definitions and draw na initial model of this process, we leveraged a theoretical review combined with analysis of fragments from media coverage of the episode that happened with the famous Brazilian influencer Gabriela Pugliesi. As a result, we got to a process made up from four stages: influencer builds reputation, expectations and vigilante behavior are established by the audience, vexing facts are exposed and then the audience reacts (the cancelation itself).

It's worth noticing that this is an initial proposal. Thus, it's necessary to go deeper in each of these phases, to delineate the process and point dynamics between influencers, audiences, and brands. Once the cancelation theme is recent and in early stages of scientific debate, future research is necessary, especially pointing to other factors that play a key role in building celebrity status for influencers, such as social capital, authority and even reputation on its own. Besides, one area that was not contemplated and deserve attention in following studies is the rebound after cancellation, which puts a question mark 


\section{Brazilian Creative Industries}

on how effective the virtual shaming goes as it relates to the financial impact and follower base of the professional under scrutiny.

\section{REFERENCES}

GABRIELA Pugliesi pode ter tido prejuízo de R\$ 3 milhões ao dar festa em quarentena. Folha de São Paulo. São Paulo, 2 de maio de 2020. Available at: https://f5.folha.uol.com.br/celebridades/2020/05/ gabriela-pugliesi-pode-ter-tido-prejuizo-de-r-3-milhoes-ao-dar-festa-em-quarentena.shtml . Access on: September 28th, 2020.

GABRIELA Pugliesi tem contratos suspensos após fazer festa durante quarentena. G1, Rio de Janeiro, 27 de abril de 2020. Available at: https://g1.globo.com/pop-arte/noticia/2020/04/27/gabriela-pugliesi-tem-contratos-suspensos-apos-fazer-festa-durante-quarentena.ghtml. Access on: September 28th, 2020.

HOU, Yubo; JIANG, Tonglin; WANG, Qi. Socioeconomic status and online shaming: the mediating role of belief in a just world. Computers in Human Behavior, v. 76, p. 19-25. Elsevier, 2017.

KARHAWI, Issaaf. Influenciadores digitais: conceitos e práticas em discussão. Comunicare, São Paulo, v. 17, p. 38-42, 2017.

NG, Eve. No Grande Pronouncements Here...: Reflections on Cancel Culture and Digital Media Participation. Television \& New Media, v. 21, n. 6, p. 621-627. Sage, 2020.

ORTIZ, Renato. As celebridades como emblema sociológico. Sociologia \& Antropologia, v. 6, n. 3, p. 669- 697, dez. 2016.

PERILO, Bruna. Gabriela Pugliesi, quem é? Biografia, carreira, vida pessoal e polêmicas. Área de Mulher R7. Available at: https://areademulher.r7.com/celebridades/gabriela-pugliesi/. Access on: September 28th, 2020.

SALLES, Stéfano. Gabriela Pugliesi é denunciada ao MP por exercício ilegal da profissão. $\mathbf{O}$ Globo, Rio de Janeiro, 20 de abril de 2017. Available at: https://oglobo.globo.com/rio/gabriela-pugliesi-denunciada-ao-mp-por-exercicio-ilegal-da-profissao-20954308. Access on: September 28th, 2020.

SHIRKY, CLAY. Here comes everybody: the power of organizing without organizations. Penguin Books, 2008. 


\section{Brazilian Creative Industries}

SOLOVE, Daniel J. The future of reputation: gossip, rumor and privacy on the internet. New Haven and London. Yale University Press, 2007.

VRIES, Amy de. The use of social media for shaming strangers: young people's views. In: Proceedings of the $\mathbf{4 8}^{\text {th }}$ Hawaii International Conference on System Sciences, p. 2053 - 2062. IEEE, Kauai. 2015. 